\title{
FARMACIJOS SPECIALISTŲ PATIRTIS, GAVUS NETINKAMAI IŠRAŠYTĄ GYDYTOJO RECEPTĄ
}

\author{
Aurimas Galkontas, Gabrielė Semenenkaitė, Kristina Perminaitė \\ Kauno kolegijos Medicinos fakultetas
}

\author{
Raktažodžiai: receptas, gydytojas, farmacijos specia- \\ listas.
}

\begin{abstract}
Santrauka
Farmacijos specialistai yra paskutinioji grandis, kurioje patikrinamas gydytojo išrašytas receptas ir parduodamas ar išduodamas vaistinis preparatas. Farmacijos specialistas, kilus neaiškumų dẻ išrašyto vaisto recepto, turi konsultuotis su gydytoju. Tarpprofesinis bendradarbiavimas šiuolaikinèje medicinoje apibūdinamas kaip procesas, kurio metu skirtingu profesijų atstovų grupès dirba kartu tam, kad būtų pasiekti geresni sveikatos priežiūros rezultatai. Farmacijos specialistų nuomone, geresnis bendradarbiavimas su gydytojais gali pelnyti didesni pacientų pasitikèjimą sveikatos priežiūros sistema. Dèl laiko trūkumo ir gydytojo nepasitikejjimo farmacijos specialisto kompetencija bendradarbiavimas vyksta neefektyviai [4].

Tyrimo tikslas - palyginti X miesto ir Y rajono farmacijos specialistų patirtį, gavus netaisyklingai išrašytą gydytojo receptą.

Tyrimo rezultatai parodé, kad klaidų gydytojų receptuose pasitaiko retai. Lyginant popierinius ir e. receptus, e. receptuose klaidų aptinkama rečiau. Analizuojant gautus rezultatus, atsakymai nežymiai skyrèsi ir paaiškejjo, jog klaidų pasitaiko retai arba vidutiniškai, tačiau rajone jų aptinkama šiek tiek daugiau, negu mieste. Dažniausiai pasitaikančios receptų klaidos - neįrašytas paciento vardas, pavarde ir gimimo data (arba, jų vietoje, ambulatorinès kortelès numeris), klaidingai parašytas vaistinio preparato pavadinimas. Aptikę klaidingai išrašytą receptą, farmacijos specialistai dažniausiai susisiekia su jị išrašiusiu gydytoju. Lyginant miesto ir rajono duomenis, rajone dažniau bendradarbiaujama su gydytojais dẻl receptų klaidų, o mieste ịžvelgiama daugiau bendradarbiavimo su gydytojais kliūčių. Beveik pusė apklaustųjų mano, jog reikalingi reagavimo ị receptų klaidas mokymai.
\end{abstract}

\section{Ivadas}

Netinkamai išrašytų gydytojų receptų aptikimas yra dažnas reiškinys sveikatos priežiūroje. Receptų klaidos kelia riziką pacientų sveikatai, todèl labai svarbu spręsti šią problemą. Farmacijos specialistai yra paskutinioji grandis, kurioje patikrinamas gydytojo receptas ir parduodamas ar išduodamas vaistinis preparatas. Farmacijos specialistas, kilus neaiškumų dẻl išrašyto vaisto recepto, turi konsultuotis su gydytoju. R. Shrestha ir S. Prajapati (2019) tyrime nustatyta, kad klaidų receptuose aptinkama dažnai. Dažniausiai pasitaikančios - nebuvo gydytojo spaudo $(87,5 \%)$ ar parašo $(19,2 \%)$ [1]. G. Velo ir P. Minuz (2009) teigimu, receptu klaidų prevencijai pasitarnautų informacijos apie klaidingus receptus gavimas ir prièmimas. Receptus rašantys gydytojai turètų būti informuoti apie jų aplinkoje padarytas klaidas [2].

Farmacijos specialistų funkcijos aprẻpia vaistų išdavimą, farmacinių paslaugų teikimą, remiantis geros vaistinių praktikos (GVP) nuostatomis, fiziologinių ir biocheminių parametrų matavimo paslaugas, pacientų gydymo plano stebèjimą, įsitraukimą į prevencinių programų vykdymą, sveikos gyvensenos patarimų teikimą bei ekstemporalių vaistinių preparatu gamybą [3].

Tarpprofesinis bendradarbiavimas šiuolaikinèje medicinoje apibūdinamas kaip procesas, kurio metu skirtingų profesijų atstovų grupès bendradarbiaudamos siekia geresnių sveikatos priežiūros rezultatų. Remiantis R. Mačernytės (2014) farmacijos specialistų nuomonès tyrimu, bendradarbiavimo didinimas gali padidinti pacientų pasitikèjimą sveikatos priežiūros sistema, tačiau dèl laiko trūkumo ir gydytojų nepasitikejimo farmacijos specialisto kompetencija, bendradarbiavimas nevyksta efektyviai [4].

Tyrimo tikslas - palyginti $\mathrm{X}$ miesto ir $\mathrm{Y}$ rajono farmacijos specialistų patirtį, gavus netaisyklingai išrašytą gydytojo receptą.

\section{Tyrimo medžiaga ir metodai}

Tyrimo duomenų rinkimo metodas - anketinè anoniminè apklausa raštu. Mokslinès literatūros ir teisès aktų, 
reglamentuojančių farmacijos veiklą Lietuvoje, analizė. Naudotas klausimynas, sudarytas iš 21 uždarojo tipo ir 2 atvirų klausimų, suskirstytų i 3 dalis: pirmojoje - farmacijos specialistų patirtis, gavus netaisyklingai išrašytą gydytojo receptą, antrojoje - farmacijos specialisto ir gydytojo bendradarbiavimo svarba, trečiojoje dalyje - sociodemografiniai klausimai. Tyrimo metu surinktų duomenu analizė atlikta Microsoft Office programinio paketo 2013 metų versijos Word ir Excel programomis, matematiniu duomenų analizès apdorojimo metodu.

Tyrimo organizavimas, eiga ir imties sudarymo principai. Tyrimas vyko 2021 metų vasario-kovo mènesiais. Tyrimo priemonè - duomenų rinkimo ir analizès metodai. Prieš pradedant tyrimą, buvo svarbu nusistatyti imties tūrị. Šiuo atveju tyrime dalyvavo X miesto ir Y rajono farmacijos specialistai. Imties tūris priklauso nuo generalinès aibès visumos - nuo populiacijos ir paklaidos dydžių. Šiame tyrime noredami gauti tikslius statistinius duomenis, tyrimo imtị skaičiavome naudodamiesi „Raosoft sample size calculator“ skaičiuokle. Valstybinès vaistų kontrolès tarnybos duomenimis, Lietuvoje 2020 m. gruodžio 31 dieną X mieste dirbo 1047, o Y rajone - 49 farmacijos specialistai. Naudojantis imties skaičiuokle, apskaičiuota (paklaida 7\%), jog norint gauti tyrimo duomenis,

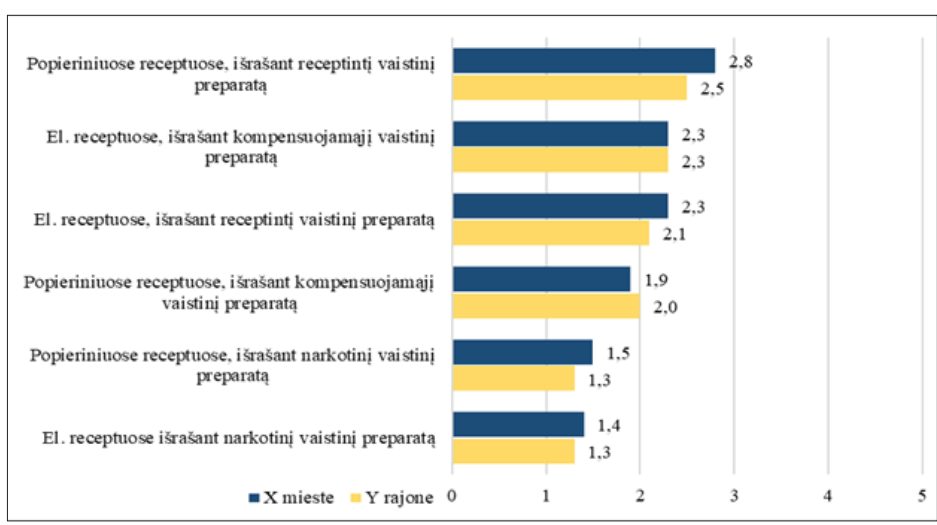

1 pav. Elektroniniuose ir popieriniuose receptuose aptinkamų išrašymo klaidų dažnis $(\mathrm{n}=138, \mathrm{n}=40)$

Pateiktas Likerto skalès vidurkis. Kuo vidurkis didesnis, respondentai labiau sutinka su pateiktu teiginiu.

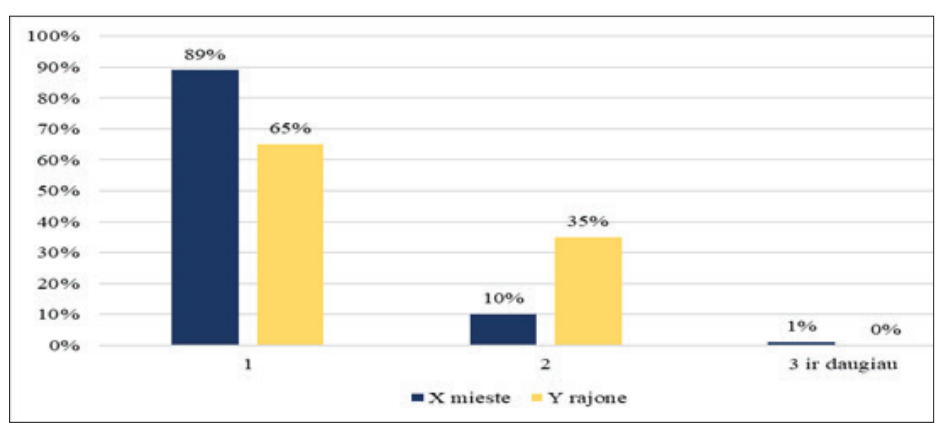

2 pav. Klaidų skaičius receptuose $(n=138, n=40)$ kurie atspindètų generalinę aibę, reikia apklausti 132 farmacijos specialistus iš $\mathrm{X}$ miesto ir 40 iš $\mathrm{Y}$ rajono. Tyrimo imtis buvo skaičiuojama su 7 (ne su 5) procentų paklaida, kadangi dèl COVID-19 pandemijos ir ribojimų visuomenès vaistinèse, nebuvo galimybės aplankyti visų X mieste esančių vaistinių ir pakviesti dalyvauti tyrime jose dirbančių farmacijos specialistų. Farmacijos specialistams buvo pateikta anoniminè anketa raštu. Gauti 138 atsakymai $\mathrm{X}$ mieste ir 40 atsakymų Y rajone. Ǐs viso buvo gautos 178 anketos, todè galima teigti, jog gauti rezultatai atspindi tiriamają populiaciją.

Tyrimo dalyviai. Iš viso tyrime dalyvavo 178 respondentai. Anonimine anketa buvo apklausti 166 farmacijos specialistai, dirbantys $\mathrm{X}$ mieste ir 42 farmacijos specialistai, dirbantys Y rajone. Iš 166 anketų $X$ mieste tinkamai užpildytos buvo 138 , iš 42 anketų Y rajone tinkamai užpildytos 40. Tolimesnè analizè atlikta su tinkamai užpildytomis 178 anketomis.

\section{Tyrimo rezultatai}

Didžiąją dalị respondentų sudarè moterys (miesto 95,7\%, rajono 90\%). Respondentai pagal amžių mieste ir rajone išsiskyrè. Mieste daugiau respondentų buvo 31-40 metų (29,7\%), rajone - 51 metų ir daugiau (31\%), t.y. rajone daugiau vyresnio amžiaus farmacijos specialistų.

Pagrindinis klausimas - ar farmacijos specialistai yra aptikę receptų išrašymo klaidų? Remiantis tyrimo duomenimis, visi farmacijos specialistai yra aptikę recepto išrašymo klaidų (mieste $100 \%$, rajone $100 \%$ ). Atsakymai parodè, kad recepto išrašymo klaidų vis dar pasitaiko, todèl gerinant pacientų sveikatą, reikia tobulinti sistemą, imtis veiksmų šalinti receptų išrašymo klaidas.

Respondentams buvo pateikti ịvairių receptų aprašymai. Naudojantis 5 balų Likerto skale $(1-$,Niekada“", 5 - „Labai dažnai“), buvo prašoma ịvertinti, kaip dažnai jų darbinèje veikloje pasitaiko recepto išrašymo klaidų, pagal kiekvieną recepto aprašymą. 1 pav. pateikiami ịvertinimų vidurkiai pagal receptų aprašymus ir X miestą bei Y rajoną. Analizuojant duomenis galime teigti, jog dažniausiai klaidų pasitaiko popieriniuose receptuose, išrašant receptini vaistinį preparatą. Lyginant šiuos vidurkius mieste ir rajone, vidurkiai skiriasi labai nežymiai. Rečiausiai pasitaikančios klaidos elektroniniuose receptuose aptinkamos išrašant narkotinị vaistini preparatą. Tokius rezultatus galime grissti tuo, jog ne visos vi- 
suomenès vaistinès turi teisę parduoti narkotinius vaistinius preparatus, todèl kai kurie farmacijos specialistai su tokiais specifiniais receptais susiduria ganètinai retai. Lyginant ši vidurkị X mieste ir Y rajone, skirtumas nepastebimas, kadangi vidurkis labai panašus (mieste 1,4, rajone 1,3).

Farmacijos specialistų buvo klausiama, kiek vidutiniškai klaidų pasitaiko receptuose. Didžioji dalis X miesto respondentų atsakè, kad pasitaiko 1 klaida (89\%), mažesnè dalis atsake, jog pasitaiko $2(2 \%)$ arba 3 ir daugiau klaidu (1\%). Y rajono respondentai atsake, jog pasitaiko $1(65 \%)$ arba 2 klaidos (35\%). Palyginę gautus rezultatus galime teigti, jog dažniau pasitaiko 1 klaida, tačiau Y rajone neretai pasitaiko ir po 2 klaidas (2 pav.).

Išsiaiškinus, kokiuose receptuose dažnesnès jų išrašymo klaidos, buvo siekiama sužinoti, kokios daromos klaidos ir kaip dažnai. Respondentams, remiantis moksline literatūra, buvo pateiktos klaidos, kurių gali pasitaikyti gydytojų išrašytuose receptuose. Prašyta ịvertinti, kaip dažnai šios klaidos pasitaiko jų darbinejje veikloje. 3 pav. pateikti įvertinimų vidurkiai X mieste ir Y rajone. Dažniausiai pasitaikančios klaidos: neįrašytas paciento vardas, pavarde ir gimimo data (arba, vietoje jų, ambulatorinès kortelès numeris), vidurkių skirtumas tarp miesto ir rajono nedidelis, tačiau mieste klaidų aptinkama šiek tiek dažniau (mieste 2,7, rajone 2,4). Dažnesnès vaistinio preparato pavadinimo klaidos, vidurkis tarp miesto ir rajono šiek tiek skyrèsi, rajone tokių klaidų aptinkama dažniau (mieste 2,5, rajone 2,9). Rečiausiai pasitaikančios klaidos - nèra gydytojo spaudo ir parašo (mieste 1,8 , rajone 2,2 ), nèra ASPI spaudo (mieste 1,9, rajone 2,0), vidurkių skirtumas tarp miesto ir rajono nežymiai skiriasi.

Neseniai baigę studijas ir pradedantys dirbti farmacijos specialistai vaistinèje nèra mokomi, kaip reaguoti ị recepto klaidas. Igūdžius jie ugdosi iš savo patirties ar stebedami kolegas, kurių kiekvienas reaguoja skirtingai, taip, kaip patys išmoko, kaupdami darbo patirti. Atliekant tyrimą, klausta, ar farmacijos specialistams reikalingi mokymai, kurie padètų reaguoti ị recepto klaidas. Respondentų nuomonès išsiskyrè. $37 \% \mathrm{X}$ miesto farmacijos specialistų atsakè, jog mokymai jiems reikalingi, taip pat $37 \%$ farmacijos specialistuc iš $\mathrm{X}$ miesto atsakè, kad mokymai jiems nereikalingi. Daugiau nei pusė Y rajono respondentų

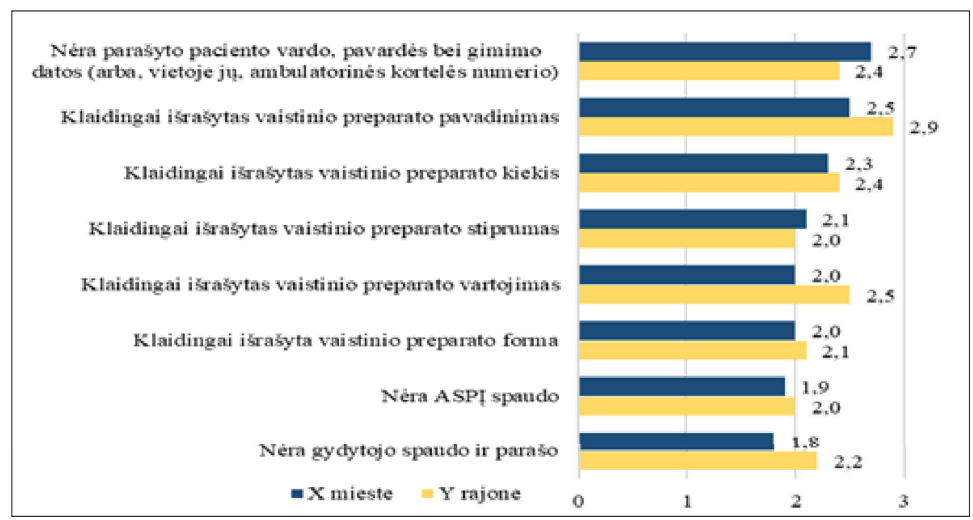

3 pav. Dažniausiai pasitaikančios receptų klaidos $(n=138, n=40)$ Pateiktas Likerto skalès vidurkis. Kuo vidurkis didesnis, respondentai labiau sutinka su pateiktu teiginiu.

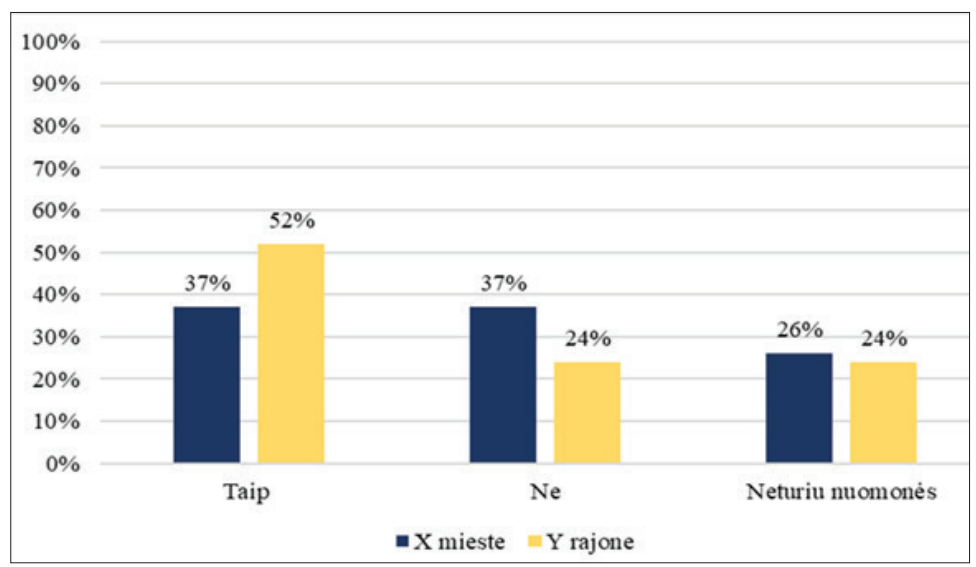

4 pav. Farmacijos specialistų nuomonè, ar reikalingi mokymai, kurie padètų reaguoti ị receptų klaidas $(\mathrm{n}=138, \mathrm{n}=40)$

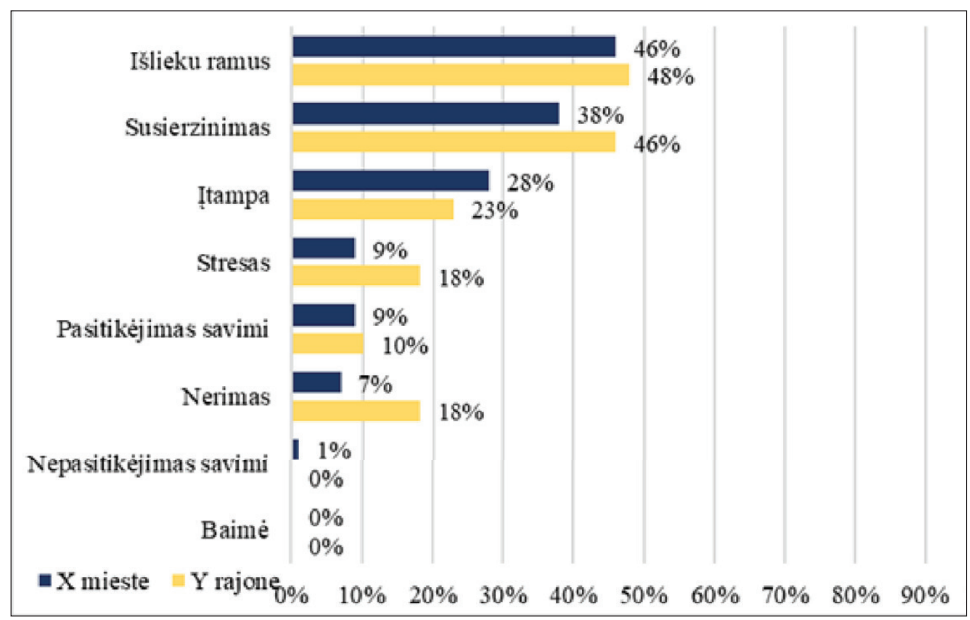

5 pav. Farmacijos specialistų emocinè būsena, gavus neteisingai išrašytą gydytojo receptą $(\mathrm{n}=138, \mathrm{n}=40)$ 


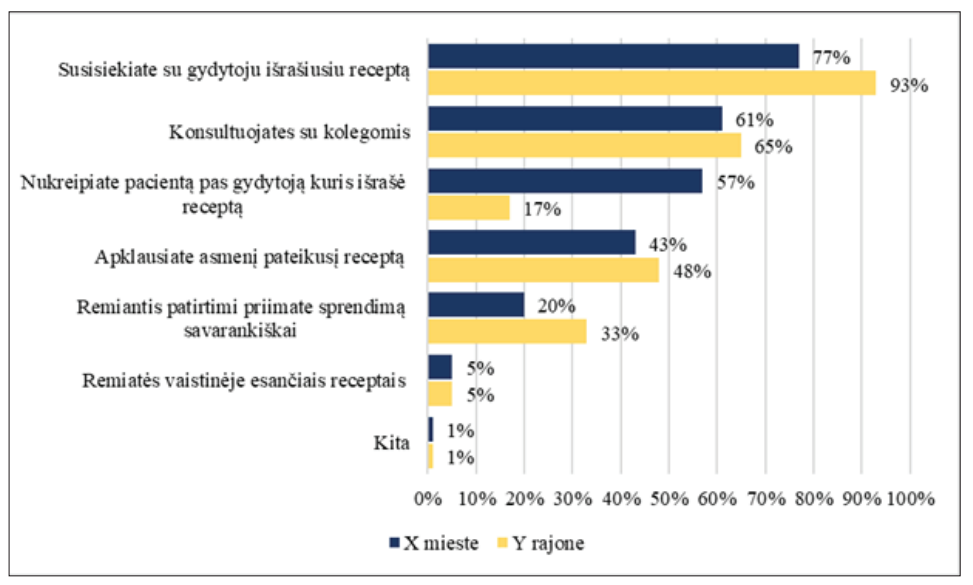

6 pav. Farmacijos specialistų veiksmai, gavus netaisyklingai išrašytą gydytojo receptą $(n=138, n=40)$

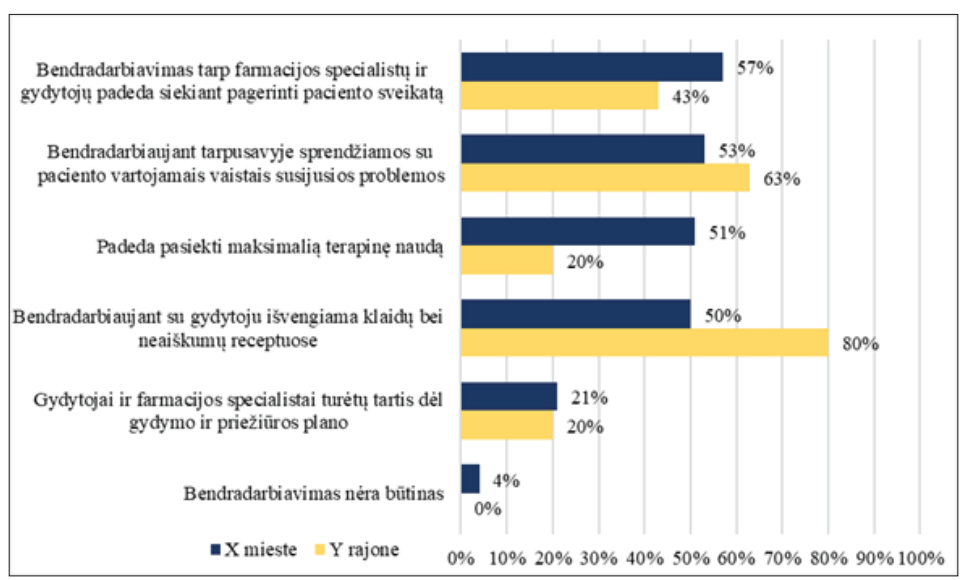

7 pav. Farmacijos specialistų nuomonė apie farmacijos specialistų ir gydytojų bendradarbiavimą $(n=138, n=40)$

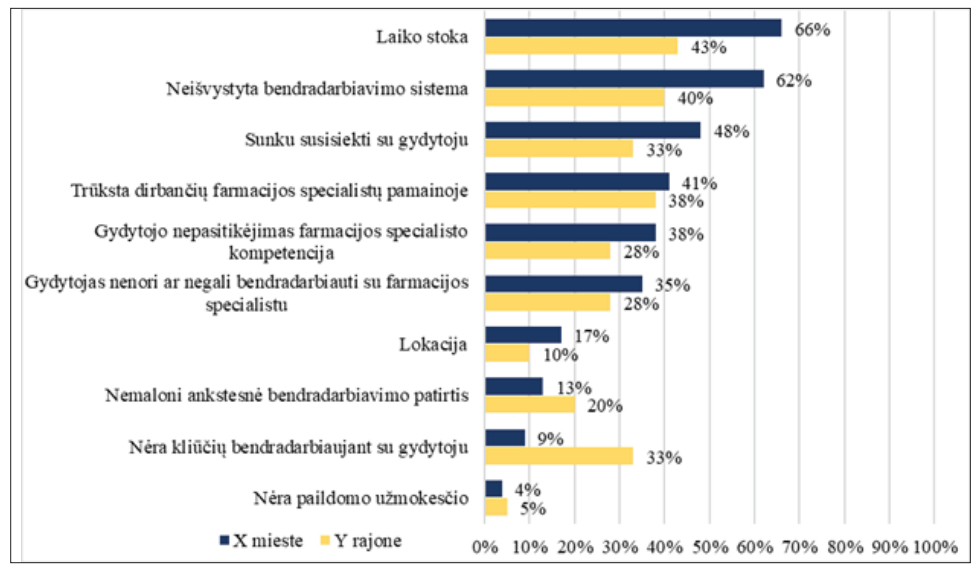

8 pav. Dažniausiai pasitaikančios farmacijos specialistų ir gydytojų bendradarbiavimo kliūtys $(\mathrm{n}=138, \mathrm{n}=40)$
(52\%) teigè, jog jiems mokymai reikalingi, o $24 \%$ $\mathrm{Y}$ rajono respondentų mokymai nereikalingi. 26\% $\mathrm{X}$ miesto ir $24 \% \mathrm{Y}$ rajono farmacijos specialistu susilaikè ir atsakè, jog neturi nuomonès. Y rajone kiek daugiau nei pusè respondentų (52\%) atsakè, jog mokymai reikalingi, mažesnè dalis atsakè, jog nereikalingi (24\%), kiti (24\%) susilaikè ir atsakè, jog neturi nuomonès (4 pav.).

Respondentai, atsakydami i klausimą, kokia jų emocinè būsena, gavus neteisingai išrašytą gydytojo receptą, galejo rinktis kelis atsakymo variantus. Gauti rezultatai parodyti 5 paveiksle. Dažniausiai farmacijos specialistai išlieka ramūs (mieste $46 \%$, rajone 48\%). Nemaža dalis jaučia susierzinimą (mieste $38 \%$, rajone $46 \%$ ) bei įtampą (mieste $28 \%$, rajone $23 \%$ ). Tokia emocinè būsena dažniausia, kai vaistinejje didelis darbo krūvis. Lyginant $\mathrm{X}$ miesto ir Y rajono respondentų atsakymus, jų nuomonès šiek tiek išsiskyrė atsakant, ar jaučia stresą (mieste $9 \%$, rajone 18\%) ir nerimą (mieste 7\%, rajone 18\%). Rajone farmacijos specialistai patiria daugiau streso ir nerimo. Nedaug respondentų jaučia pasitikèjimą savimi, priimdami sprendimus (mieste $9 \%$, rajone $10 \%$ ).

Siekta išsiaiškinti, kokie ịprastiniai farmacijos specialistų veiksmai, gavus netaisyklingai išrašytą gydytojo receptą. Respondentai galëjo pasirinkti po kelis atsakymo variantus. Didžioji dalis respondentų atsakè, jog susisiekia su gydytoju, išrašiusiu receptą. Lyginant $\mathrm{X}$ miesto ir $\mathrm{Y}$ rajono respondentų atsakymus, rajone daugiau farmacijos specialistų susisiekia su receptą išrašiusiu gydytoju (mieste $77 \%$, rajone 93\%). I atsakymo variantą, jog siunčia pacientą pas gydytoją, kuris išrašè receptą, miesto ir rajono respondentų atsakymai išsiskyre (mieste $57 \%$, rajone $17 \%$ ). Mieste daugiau nei puse farmacijos specialistų siunčia pacientą pas gydytoją, kuris išrašè receptą. Taip gali būti dèl didesnio darbo krūvio miesto vaistinèse nei rajono ir dèl to, jog neretai būna sunku susisiekti su gydytoju. Mažiausia dalis respondentų atsakè, jog remiamasi vaistineje jau surinktais receptais (mieste 5\%, rajone 5\%). Respondentai, pasirinkę variantą ,kita“, galèjo įrašyti savo veiksmus, gavus netaisyklingai išrašytą receptą. Pasitaikè respondentų, nurodžiusių, kad tokiu atveju situaciją aptaria su pacientu (mieste 1\%), arba atsako vaistinès pacientui, kad neturi reikiamo vaisto ir išsiunčia ị kitą vaistinę (rajone 1\%). Taip elgiasi 
farmacijos specialistai, vengdami išduoti netinkamą vaistini preparatą dèl klaidingai išrašyto recepto ir dẻl laiko stokos ar nemalonios ankstesnès patirties nenorintys bendradarbiauti su gydytoju.

Anketoje buvo pateikti keli klausimai apie farmacijos specialisto ir gydytojo bendradarbiavimo svarbą. Respondentams buvo galima rinktis kelis atsakymo variantus (7 pav.). Atsakymai pasiskirste ịvairiai, dauguma sutiko, jog bendradarbiavimas tarp farmacijos specialistų ir gydytojų padeda siekti paciento sveikatos gerinimo (mieste $57 \%$, rajone 43\%). Daugiau nei pusè respondentų sutiko, jog bendradarbiaujant tarpusavyje sprendžiamos su paciento vartojamais vaistais susijusios problemos. Mieste šį variantą rinkosi šiek tiek mažiau respondentų (53\%), nei rajone (63\%). Didžioji dalis respondentų sutiko su teiginiu, jog bendradarbiaujant su gydytoju išvengiama klaidų bei neaiškumų receptuose (mieste 50\%, rajone 80\%). Penktadalis apklaustujų teigè, jog gydytojai ir farmacijos specialistai turetų tartis dèl gydymo ir priežiūros plano (mieste $21 \%$, rajone $20 \%$ ). Keletas X miesto (4\%) respondentu sutiko su teiginiu, jog farmacijos specialisto ir gydytojo bendradarbiavimas nèra būtinas.

Toliau siekta išsiaiškinti farmacijos specialistų nuomonę apie dažniausiai pasitaikančias farmacijos specialistų ir gydytojų bendradarbiavimo kliūtis. Respondentams buvo galima pasirinkti daugiau nei vieną atsakymo variantą ( 8 pav.). Nuomonès pasiskirstè ịvairiai, didesnè dalis respondentų pažymejjo, jog bendradarbiauti trukdo laiko stoka (mieste $66 \%$, rajone $43 \%$ ).

Dažnas atvejis, kai pamainoje trūkstant farmacijos specialistų, bendradarbiauti su gydytojais trukdo didelis darbo krūvis, tenkantis vienam farmacijos specialistui. Miesto ir rajono respondentai panašiai sutiko, jog bendradarbiavimui trukdo pamainoje dirbančių farmacijos specialistų trūkumas (mieste $41 \%$, rajone $38 \%$ ). Rajono farmacijos specialistai nemato daug kliūčių bendradarbiauti su gydytojais (mieste $9 \%$, rajone $33 \%$ ). Keletui respondentų bendradarbiauti trukdo papildomo užmokesčio nebuvimas (mieste $-4 \%$, rajone $-5 \%$ ).

Apibendrinant galima teigti, jog klaidų gydytojų išrašytuose receptuose pasitaiko retai. Lyginant popierinius ir e. receptus, klaidos rečiau aptinkamos e. receptuose. Analizuojant gautus rezultatus, atsakymai nežymiai skyrèsi ir paaiškejjo, jog klaidų aptinkama retai arba vidutiniškai, tačiau rajone jų pasitaiko šiek tiek daugiau, negu mieste. Dažniausios receptų klaidos - nèra paciento vardo, pavardès ir gimimo datos (arba, vietoje jų, ambulatorinès kortelès numerio), klaidingai parašytas vaistinio preparato pavadinimas. Aptikę klaidingai išrašytą gydytojo receptą, farmacijos specialistai dažniausiai susisiekia su jị išrašiusiu gydytoju. Lyginant miesto ir rajono duomenis, rajone dažniau bendradarbiau- jama su gydytojais dèl receptų klaidų, o mieste ịžvelgiama daugiau bendradarbiavimo su gydytojais kliūčių. Beveik pusè apklaustujų mano, jog būtų reikalingi mokymai, kaip reaguoti ị recepto klaidas.

\section{Išvados}

1. Tyrimo metu paaiškèjo dažniausiai pasitaikančios klaidos gydytojų išrašytuose receptuose. X mieste - neirrašytas paciento vardas, pavarde ir gimimo data (arba, vietoje jų, ambulatorinès kortelès numeris), klaidingai parašytas vaistinio preparato pavadinimas; $\mathrm{Y}$ rajone - klaidingas vaistinio preparato pavadinimas ar vartojimo būdas. Vertinat gautus bendrus miesto ir rajono ịvertinimo vidurkius, galime teigti, kad klaidų dažnumas mieste ir rajone panašus. Dažniausiai recepte aptinkama viena klaida.

2. Atlikto tyrimo rezultatai atskleide, jog daugiau nei pusè $\mathrm{X}$ miesto farmacijos specialistų, aptikę recepto išrašymo klaidą, susisiekia su jị išrašiusiu gydytoju, konsultuojasi su kolegomis arba siunčia pacientą pas gydytoją, kuris išrašè receptą. Didžioji dalis Y rajono farmacijos specialistų, aptikę recepto klaidą, susisiekia su jị išrašiusiu gydytoju arba konsultuojasi su kolegomis. Daugiau nei puse X miesto farmacijos specialistų siunčia pacientą pas receptą išrašiusị gydytoją, nes ne visada lengvai pavyksta susisiekti su gydytojais (mažiau nei pusè respondentų atsakè, jog sunku susisiekti su gydytojais). Rajone šiek tiek lengviau susisiekti su gydytojais, nei mieste. Farmacijos specialistų nuomone, bendradarbiavimui trukdo laiko stoka, neišvystyta bendradarbiavimo sistema ir tai, jog sunku susisiekti su gydytojais. Mieste įžvelgiama daugiau bendradarbiavimo kliūčių nei rajone.

\section{Literatūra}

1. Shrestha R, Prajapati S. Assessment of prescription pattern and prescription error in outpatient Department at Tertiary Care District Hospital, Central Nepal. J Pharm Policy Pract 2019;12(1):1-9.

https://doi.org/10.1186/s40545-019-0177-y

2. Velo GP, Minuz P. Medication errors: Prescribing faults and prescription errors. Br J Clin Pharmacol 2009;67(6):624-8.

https://doi.org/10.1111/j.1365-2125.2009.03425.x

3. Dèl geros vaistinių praktikos nuostatų patvirtinimo. Lietuvos Respublikos Sveikatos apsaugos ministro 2007 m. birželio 15 d. įsakymas Nr. V-494 (Aktuali suvestinė redakcija 2021-0301). Valstybės žinios, 2007-06-21, Nr. 68-2690.

4. Mačernytė R. Kauno miesto visuomenès vaistinèse, esančiose netoli gydymo ịstaigų, dirbančių farmacijos specialistų požiūrio i gydytojo ir vaistininko bendradarbiavimą tyrimas: magistro baigiamasis darbas. Kaunas: Lietuvos sveikatos mokslų universitetas; 2014:26-43. 
EXPERIENCES OF PHARMACISTS ON RECEIPT OF INCORRECT DOCTOR'S PRESCRIPTIONS

\section{A. Galkontas, G. Semenenkaitė, K. Perminaitè}

Keywords: prescription, physician, pharmacist.

\section{Summary}

Pharmacists are the last link in checking a doctor's prescription and selling or dispensing a medicine. The pharmacist should consult a physician in case of doubt as to the prescription. Interprofessional collaboration in modern medicine is described as a process in which groups of different professions work together to achieve better health outcomes. According to pharmacists, better collaboration with physicians can lead to greater patient confidence in the health care system. However, due to lack of time and underestimation of doctors' lack of confidence in the competence of a pharmacist, cooperation is not effective [4].

Errors in prescribed doctor's prescriptions are rare when comparing paper and e. prescription errors are less common. Analy- zing the results obtained, the answers differed slightly and it turned out that errors were found rarely or moderately, but slightly more errors were found in the district than in the city. The most common mistakes in prescriptions are that the patient's name and date of birth (or, instead, the outpatient card number) are not written, and the name of the medicine is misspelled. When a doctor's prescription is found incorrectly, pharmacists usually contact the doctor who issued the prescription, comparing the data received by the city and district, there is more cooperation with doctors in the district due to prescription errors, and the city sees more obstacles to cooperation with doctors. Nearly half of those surveyed believe that training is needed to help them respond to prescription errors.

Correspondence to: aurimas.galkontas@go.kauko.lt

Gauta 2021-10-15 